\title{
Rainfall distribution over the Fouta Djallon - Guinea
}

\author{
Saïdou Moustapha Sall ${ }^{\mathrm{a}}$, Alain Viltard ${ }^{\mathrm{b}}$, Henri Sauvageot ${ }^{\mathrm{c}, *}$ \\ a Université Cheikh Anta Diop, Ecole Supérieure Polytechnique, Laboratoire de Physique de l'Atmosphère et de l'Océan Siméon Fongang, \\ Dakar, Sénégal \\ ${ }^{\mathrm{b}}$ Institut Pierre-Simon Laplace, Ecole Polytechnique, Laboratoire de Météorologie Dynamique, Paris, France \\ ${ }^{\mathrm{c}}$ Université Paul Sabatier, Observatoire Midi-Pyrénées, Laboratoire d'Aérologie, Toulouse, France
}

\begin{abstract}
The main goal of the present paper is to discuss the asymmetry of the rainfall distribution over the mountain range of the Fouta Djallon — Guinea - in relation with orography and local atmospheric circulation. The Fouta Djallon is the main West African hydrographic source area. The two principal rivers (Niger and Senegal) take birth in this region where, in addition, one of the highest cumulative rain heights in the world $(>10 \mathrm{~m})$ is observed. The data used are images of the Meteosat satellite, reanalyses of NCEP/NCAR (National Center for Environmental Prediction/National Center for Atmospheric Research) and ECMWF (European Centre for Medium-Range Weather Forecasts), and observations from ground-based raingauge networks. Over the Fouta Djallon, the convective activity is found to increase in frequency and intensity due to the orographic forcing of water vapor in an area of convergence between monsoon and Harmattan fluxes; heavy rain is released over the southwest side of the range. A conceptual model is proposed suggesting that convective systems developing over or east of the range are advected westward of the generating area, resulting in a strong pluviometric contrast and a maximum offshore.
\end{abstract}

\section{Introduction}

The Fouta Djallon is located near the West African Coast (Fig. 1). It is composed of two massifs, one centred around $11^{\circ} \mathrm{N}$ and $12^{\circ} \mathrm{W}$ and the other around $8^{\circ} \mathrm{N}$ and $9^{\circ} \mathrm{W}$. The area is under the southwesterly monsoon wind regime between approximately $1000 \mathrm{hPa}$ and $800 \mathrm{hPa}$ and under easterly wind above $800 \mathrm{hPa}$.

\footnotetext{
* Corresponding author. Université Paul Sabatier, Observatoire Midi-Pyrénées, Laboratoire d'Aérologie, 65300 Lannemezan, France. E-mail address: sauh@aero.obs-mip.fr (H. Sauvageot).
}

The West African monsoon is a thermally direct landocean-atmosphere coupled circulation driven by the meridional gradients of dry and moist static energy that develops in the boundary layer between the Gulf of Guinea and the continent. During spring the moist static energy of the atmosphere increases over West Africa mainly through surface warming. Dry convection converts enthalpy into geopotential energy and thus enables an overturning in the circulation over West Africa. All favors the advection of water vapor from the Atlantic, convergence in low levels, deep convection and rainfall. This circulation maintains in summer. The monsoon circulation combines several wind components. 


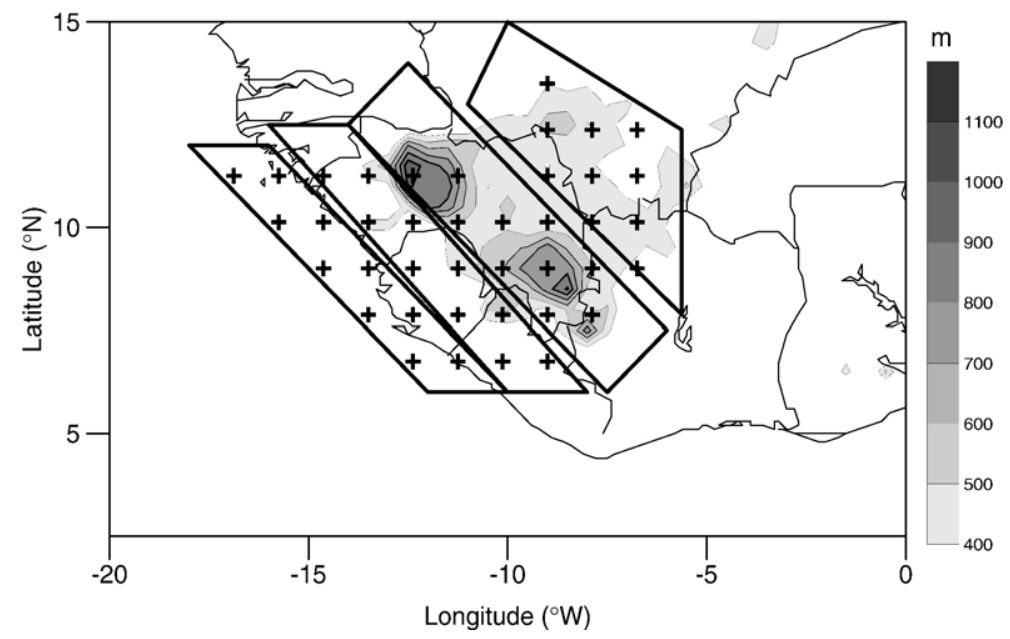

Fig. 1. Selected areas over and around the Fouta Djallon (FD) and grid points used for ERA 40 (ECMWF reanalyses). There are ten grid points in each area. These areas are designed from west to east "ocean, west-FD, FD, and east-FD". The grey levels represent relief of the Fouta Djallon. Isolines are $100 \mathrm{~m}$ from each other, from $400 \mathrm{~m}$ upward.

The southwesterly monsoon flows in low levels, the African Easterly Jet (AEJ) in the mid troposphere, the Tropical Easterly Jet (TEJ) from June to September by $5-10^{\circ} \mathrm{N}$ and the subtropical westerly jet by $30-35^{\circ} \mathrm{N}$. AEJ is due to strong south-north thermal gradients near to the surface and to a transverse circulation driven by the Saharan heat low. In March it blows south of the Guinea Coast and from March to August migrates northward. The deep convection generating the rainbelt is located around $10^{\circ} \mathrm{N}$ from July to September. To sum up, the West African monsoon circulation results from a combination and scale interactions between moist convection in the intertropical convergence zone (ITCZ), dry convection in the transverse circulation of the thermal depression, easterly waves, AEJ and moisture flux convergence in low levels (Plumb and Hou, 1992; Hastenrath, 1995; Eltahir and Gong, 1996; Thorncroft and Blackburn, 1999; Nicholson and Grist, 2003).

Consequently the climate of the Fouta Djallon area is wet equatorial with alternation of a dry season from September to April and a rainy season from May to October providing an average rainfall height higher than $2000 \mathrm{~mm}$ over the coastal area of Guinea. Isohyets of annual rainfall averaged over half a century (19251975; Fig. 2) display a strong gradient southwest of the Fouta Djallon Massif (Nicholson et al., 1988). The rainfall height varies strongly in space and time during a single rainy season and from one year to the other.

The Fouta Djallon is the source of the West African hydrographic network. Notably, the Niger and the Senegal, the two main rivers of the region, take birth in these mountains and run long pathes before flowing into the Atlantic Ocean.

Many authors have discussed the formation and evolution of precipitating cloud systems over West Africa and over the near Atlantic Ocean (Houze, 1977; Martin and Schreiner, 1981; Desbois et al., 1989; Arlene et al., 1993; Rowell and Milford, 1993; Sall et al., 1999; Mathon and Laurent, 2001; Gaye et al., 2005; Sall and Sauvageot, 2005; Sall et al., 2006, among others).

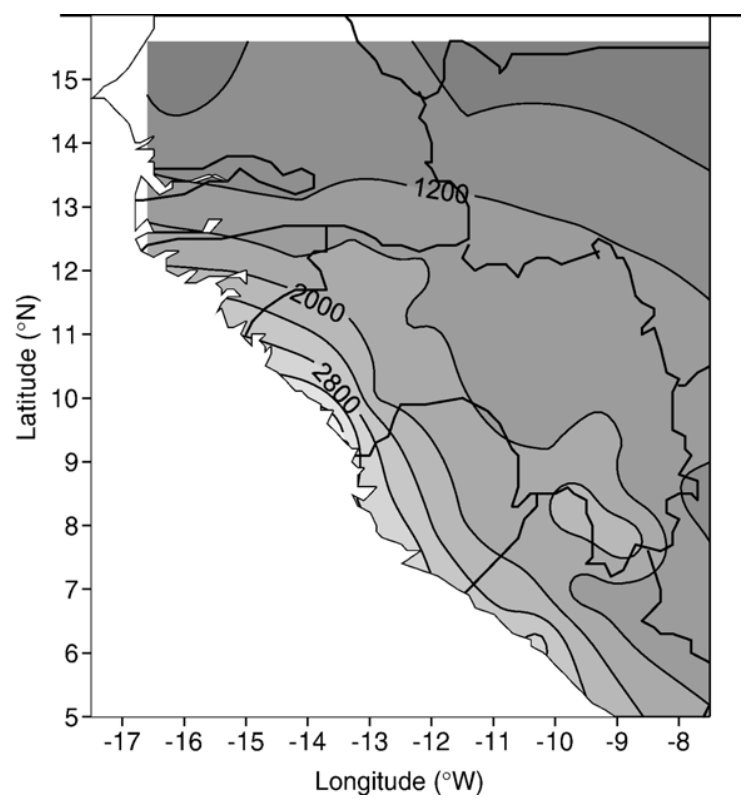

Fig. 2. Isohyets, in $\mathrm{mm}$, over the Fouta Djallon area (from data of Nicholson et al. 1988). 

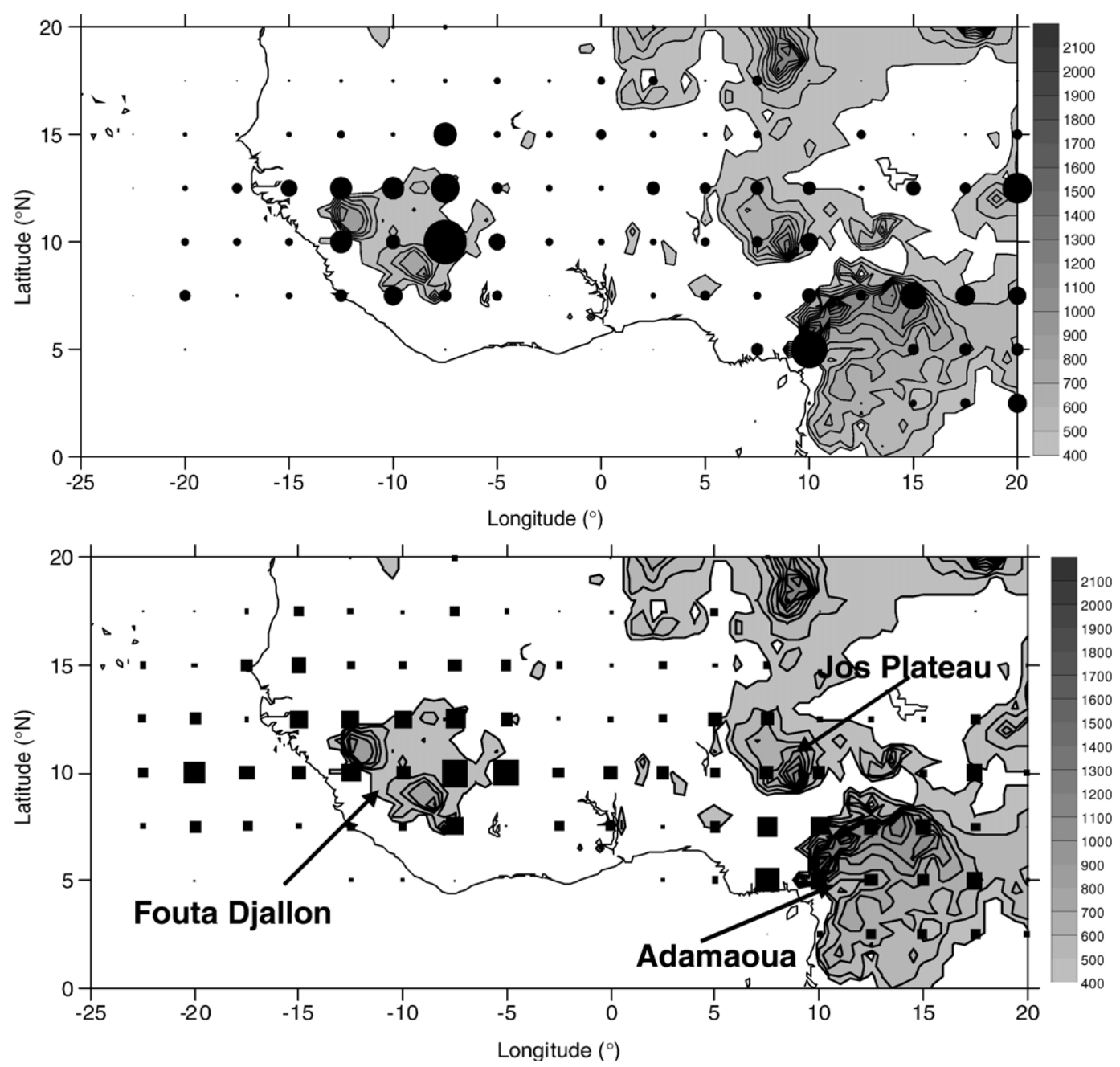

Fig. 3. Number of generation (upper panel) and dispersal (lower panel) of convective systems between July and September 1993 in each grid mesh of $2.5^{\circ} \times 2.5^{\circ}$, obtained from data of the Meteosat satellite. The isocontours represent relief.

However, few of these have tackled the role of orography, notably of the Fouta Djallon, on the distribution of convection and precipitation. Sall et al. (1999) found that mesoscale precipitating systems in West Africa are generated over areas with particular orographic features.

Fig. 3 presents the distribution of the number of convective system generations (formation of systems having a lifetime longer than $6 \mathrm{~h}$ and an equivalent area equal or larger than a circle of radius $100 \mathrm{~km}$ for a brightness temperature lower than $-38{ }^{\circ} \mathrm{C}$ ) and dispersals (systems losing the minimum area condition) over West Africa between July and September 1993 inside elementary areas of $2.5^{\circ} \times 2.5^{\circ}$ (Sall et al. 1999). It shows that the two regions located at longitude interval $\left(-20^{\circ},-5^{\circ}\right)$ and $\left(5^{\circ}, 20^{\circ}\right)$ are particularly effective as sources and sinks of convective systems.
These two regions correspond to the two main reliefs of West Africa: the Fouta Djallon in Guinea, in the western part, and the Jos Plateau and Adamaoua Massif in the eastern part (Fig. 3). The central part, between $-5^{\circ}$ and $5^{\circ}$ of longitude is a region of minimum of generationdispersal. In latitude, convective activity is mainly located between $5^{\circ}$ and $15^{\circ}$ north.

Fig. 4 displays the wind vectors seasonally (June, July, August, and September - JJAS) averaged over 23 years (1979-2001), from the ERA 40 data set, at 600 and $925 \mathrm{hPa}$. It shows that south $15^{\circ} \mathrm{N}$, west of Atlantic Coast, airflow at low level is eastward and reverse westward at upper levels.

Fig. 5 illustrates the effects of the Fouta Djallon on vertical air motion. It shows the projection in the vertical plan of latitude $10^{\circ} \mathrm{N}$, between $30^{\circ} \mathrm{W}$ and $30^{\circ} \mathrm{E}$, of the 

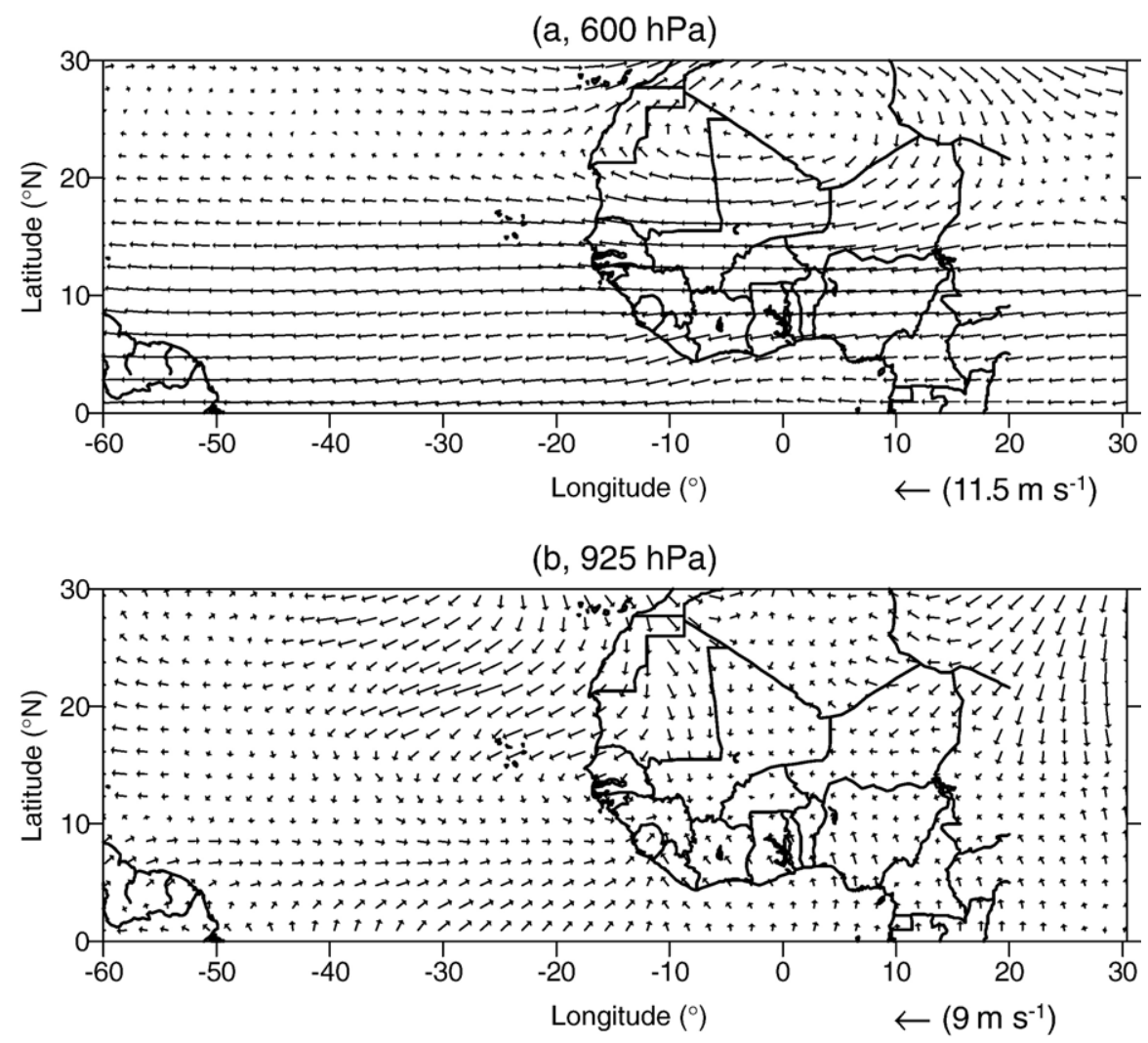

Fig. 4. Wind field averaged over 23 years (1979-2001) at a) $600 \mathrm{hPa}$, and b) $925 \mathrm{hPa}$ (from ERA 40).

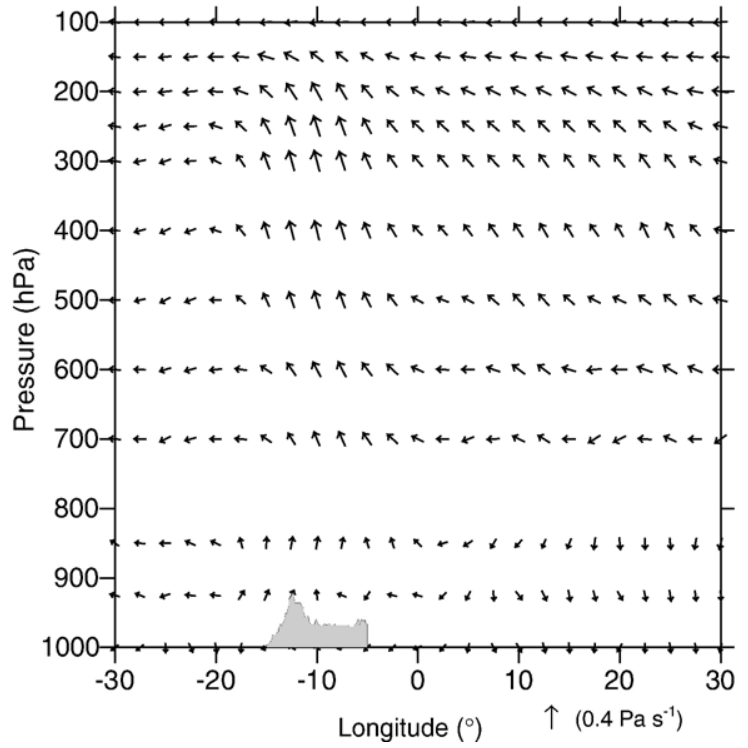

Fig. 5. Wind vector at 18:00 UTC in August averaged from 1989 to 1998 , in projection in the vertical plan of latitude $10^{\circ} \mathrm{N}$. Relief around $10^{\circ} \mathrm{W}$ is the Fouta Djallon. The maximum vertical wind is $0.4 \mathrm{~Pa} \mathrm{~s}^{-1}$ (computed from the reanalyses of NCEP/NCAR — from Sall and Gaye, 2003). air velocity at 18:00 UTC in August averaged over the 1989-1998 period (period for which the satellite data and the reanalyses of models were available for us at the time of the study). Over the Fouta Djallon, an upward air motion is clearly observed from the surface up to an altitude of $200 \mathrm{hPa}$. Between 00:00 and 06:00 UTC, the updraft does not exceed the $850 \mathrm{hPa}$ level (figure not shown).

The goal of the present paper is to associate images of the infrared channel of the Meteosat satellite, rainfall data from raingauge networks, and reanalyses of NCEP/ NCAR (National Center for Environmental Prediction/ National Center for Atmospheric Research) and ECMWF (European Centre for Medium-Range Weather Forecasts, data base ERA 40 - ECMWF reanalyses over 40 years) models to describe the mesoscale convective systems and the precipitation distribution developing in relation with the Fouta Djallon Massif. A more general objective is to better understand the influence of orography on precipitation in West Africa although the analysis of the differences between the Fouta Djallon and the Mount Cameroun-Adamaoua areas is out of the scope of the present paper because the 
two areas are very different from a meteorological point of view.

\section{Data}

Reanalyses of NCEP/NCAR and of ECMWF (ERA 40) are used to characterize atmospheric conditions over West Africa, notably for each of the four regions defined over the Fouta Djallon (Fig. 1). These reanalyses combine observations (from satellites and ground-based meteorological networks) and forecasting models. The NCEP/NCAR model provides distributions of surface parameters, surface fluxes and upper level distribution parameters (air temperature, geopotential, and three components of wind velocity) over 17 levels of pressure (from 1000 to $10 \mathrm{hPa}$ ) in a grid with a $2.5^{\circ} \times 2.5^{\circ}$ mesh. The model also provides the specific humidity between 1000 and $300 \mathrm{hPa}$ for the same grid and levels. Four networks are available per day $(00,06,12$ and 18 UTC). Details on the calculation of the NCEP/NCAR reanalyses are given by Kalnay et al. (1996). Reanalyses of ECMWF (ERA 40) are drawn in the same way as those of NCEP/NCAR, using different models and observation data sets. Reanalyses of ECMWF have a resolution of $1.125^{\circ} \times 1.125^{\circ}$. Discussions about the validity of these reanalyses over West Africa can be found in many papers (e.g. Diedhiou et al. 1999; Grist and Nicholson, 2001).

Data on the outgoing longwave radiation (OLR) at the top of the atmosphere are used to describe the cloud cover over the studied area. Images of the Meteosat satellite with a temporal resolution of $30 \mathrm{~min}$ and a space resolution of $5 \mathrm{~km} \times 5 \mathrm{~km}$ at satellite nadir are used to follow cloud motion and evolution with the algorithm developed by Arnaud et al. (1992) and Laurent (1996). This algorithm enables to analyse statistical distribution, diurnal cycle, travelled distance and average velocity of convective systems. The temperature level of $-38{ }^{\circ} \mathrm{C}$ is used to separate precipitating clouds from the others. This level is considered by many authors as relating cloud top area with ground rainfall through the GPI (Global Precipitation Index) approach (notably Arkin 1979; Arkin and Meisner 1987; Kebe et al., 2005 over West Africa). To minimize the errors linked to small cloud clusters and stratiform clouds, the systems with an equivalent horizontal area smaller than a circular area of $100 \mathrm{~km}$ of diameter have been rejected. Similar criteria were used by Mathon and Laurent (2001) to study the life cycle of mesoscale convective systems over the Sahel. Data from Nicholson et al. (1988) are used to
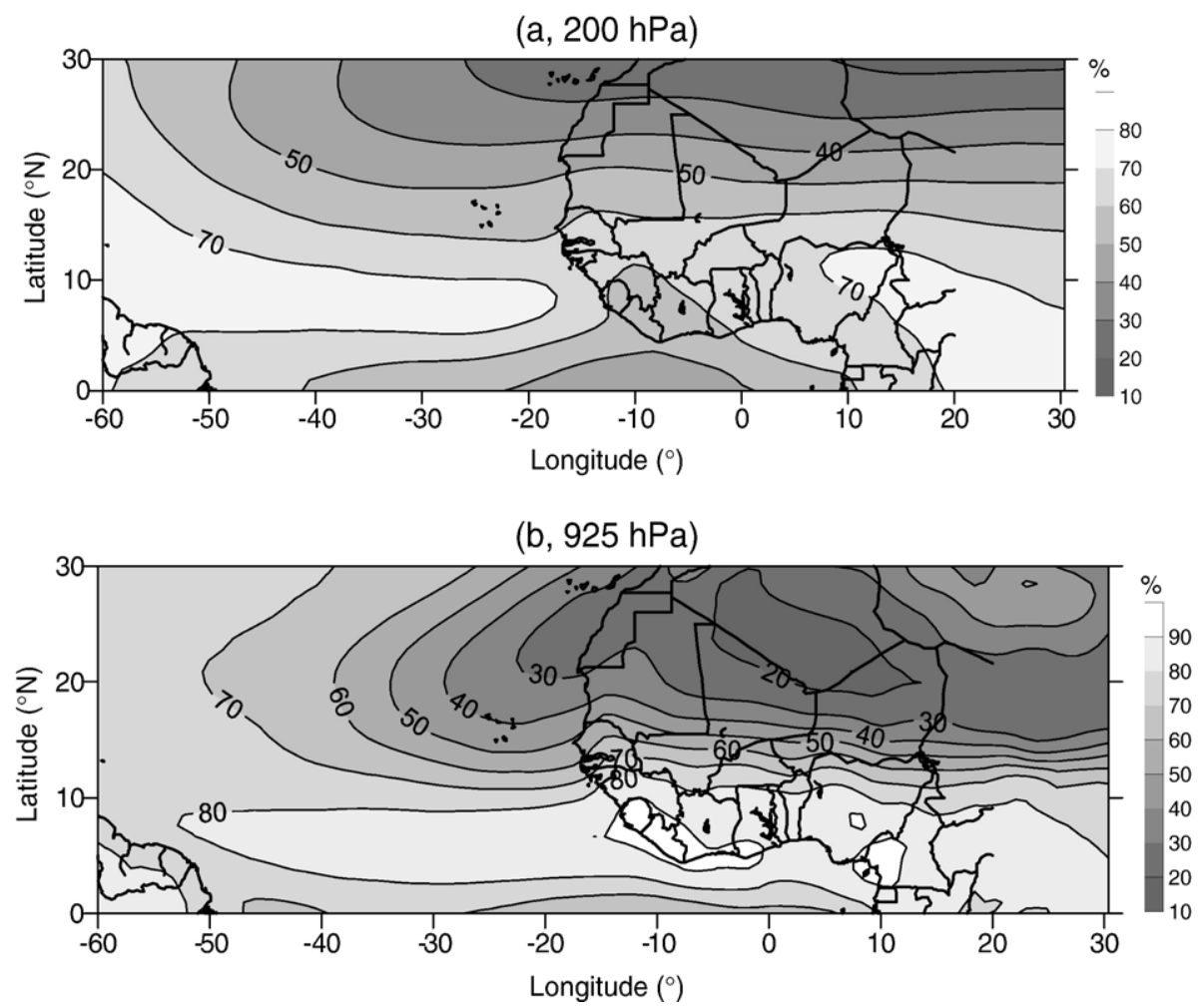

Fig. 6. Relative humidity averaged over 23 years (1979-2001) at a) $200 \mathrm{hPa}$ and b) $925 \mathrm{hPa}$. Isolines are in percent (from reanalyses of ERA 40). 


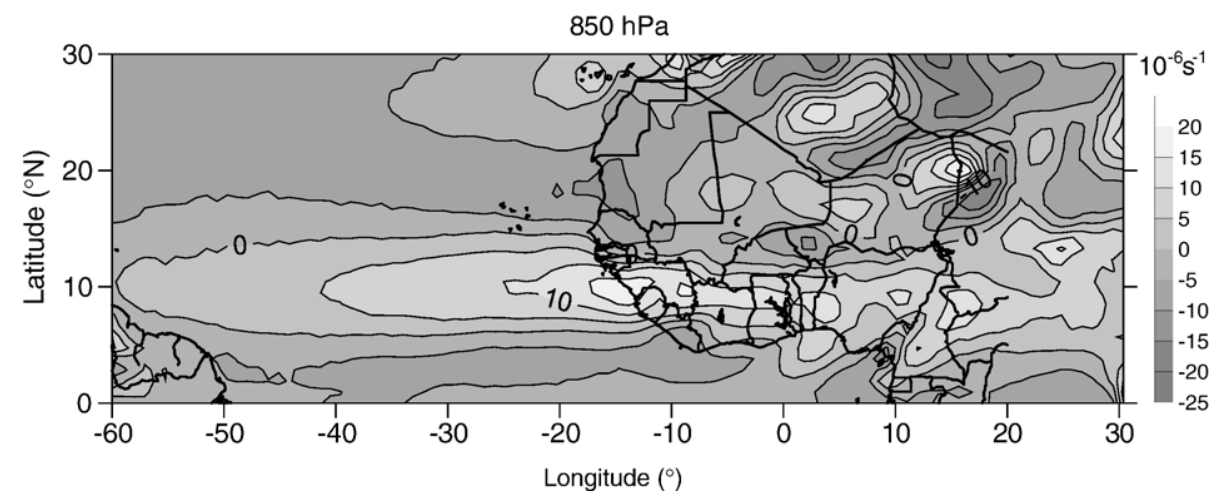

Fig. 7. Same as Fig. 6 for relative vorticity at $850 \mathrm{hPa}$. Isolines are in $10^{-6} \mathrm{~s}^{-1}$.

describe the variability of the monthly rainfall height in some ground sites distributed over the relief of the Fouta Djallon.

\section{Results and discussion}

\subsection{Large-scale analysis}

Fig. 6 displays the relative seasonal (JJAS) humidity averaged over 23 years (1979-2001) at 925 and $200 \mathrm{hPa}$.
A strong north-south gradient is observed at $925 \mathrm{hPa}$ between $10^{\circ} \mathrm{N}$ and $15^{\circ} \mathrm{N}$. The relative humidity maximum at low level is over the southwest side of the Fouta Djallon and over the Mount Cameroun area, around $10^{\circ} \mathrm{E}$. This distribution is related to the combined effect of ITCZ, monsoon circulation, and orography. At $200 \mathrm{hPa}$ the relative humidity is high over the ocean but lower over the reliefs.

For a relative seasonal (JJAS) vorticity at $850 \mathrm{hPa}$ (Fig. 7), the highest values are west of the Fouta Djallon

(a, 600hPa)

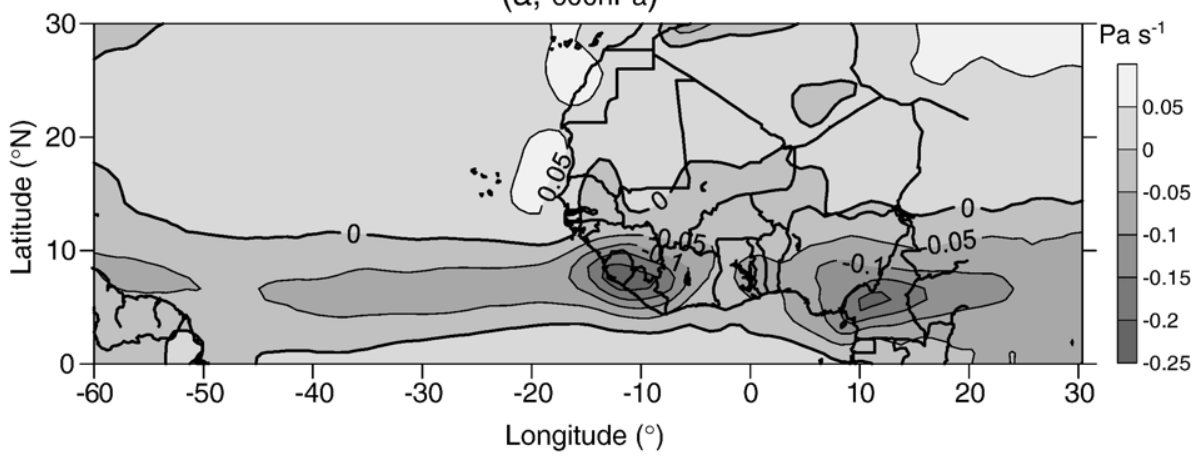

(b, $925 \mathrm{hPa})$

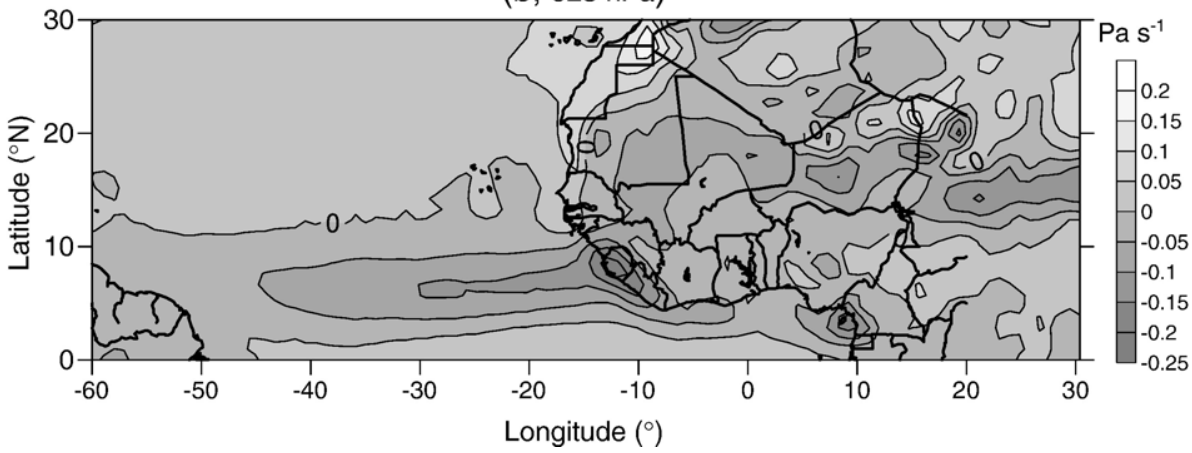

Fig. 8. Same as Fig. 6 for vertical wind velocity at a) $600 \mathrm{hPa}$ and b) $925 \mathrm{hPa}$. Isolines are in $\mathrm{Pa} \mathrm{s}$. 

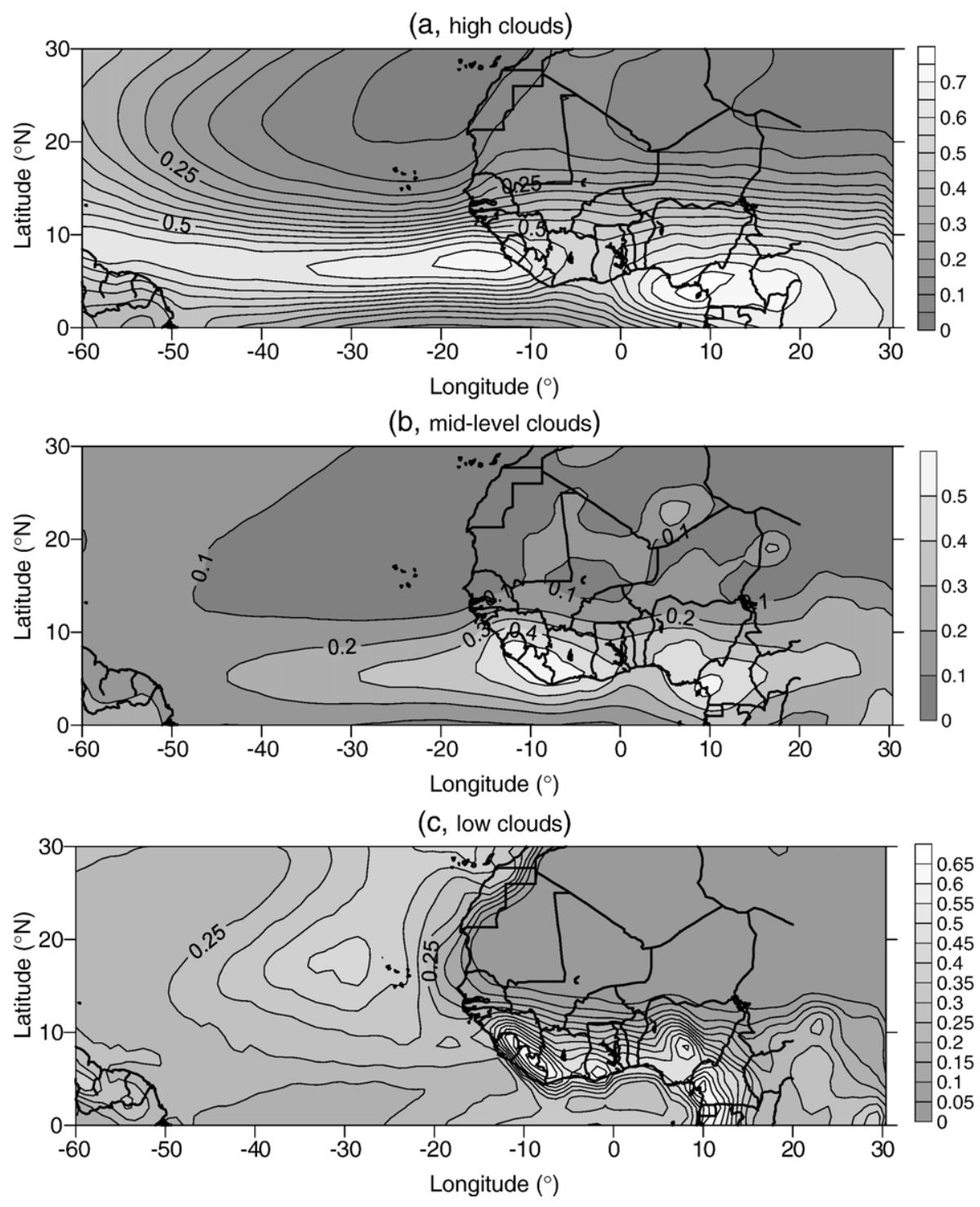

Fig. 9. Same as Fig. 6 for fractional cloud cover for a) high clouds, b) mid-level clouds, and c) low level clouds. Isolines without unit.

and, over the ocean, near the coast in relation with the strong convergence of middle tropospheric layer fluxes over this area. This circulation provides water vapor for the growth of convective systems. Consequently, strong updrafts are observed west of the reliefs as shown in Fig. 8 where the seasonally (JJAS) averaged vertical air velocity at 600 and $925 \mathrm{hPa}$ is displayed. This is the area where the cumulative rainfall is the highest (Fig. 2). A similar situation is observed around Mount Cameroun where large cumulative rainfall heights are observed.

Seasonally (JJAS) averaged cloud cover distribution appears in Fig. 9 for upper, middle, and low tropospheric levels. The maximum of upper level cloud cover is located near the coast and stretches westward over more than $1000 \mathrm{~km}$, which corresponds to the observed precipitation (Fig. 2) and to the convective precipitation forecasted for the same season and period by ERA 40 as shown in Fig. 10. Maxima for middle and low level clouds are located over the southwestern side of the reliefs, over a smaller area than the deep convective clouds and convective precipitation. Stratiform clouds and stratiform precipitation are caught on to the southwestern side of the reliefs. In the Mount Cameroun and Adamaoua areas, the westward stretching of the high level clouds is much more limited but a wide area of high clouds is observed to the east, due to the lie of the relief.

To sum up, it appears that mountainous areas strongly modify the distribution of the studied meteorological 

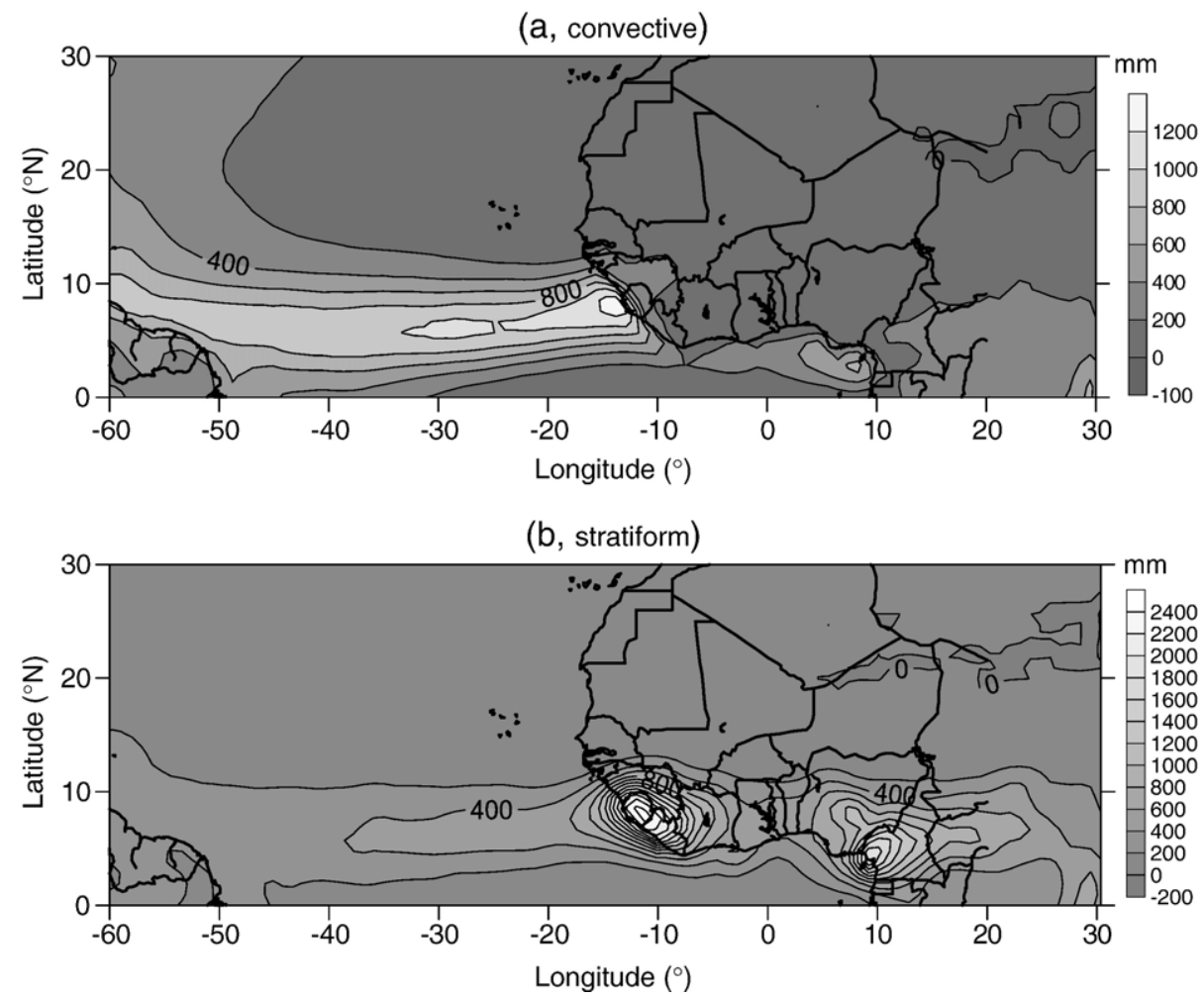

Fig. 10. Same as Fig. 6 for convective (a) and stratiform (b) rainfalls. Isolines are in $\mathrm{mm}$.

parameters, notably the Fouta Djallon which is associated with an intense convective activity over its southwestern side. Analysis suggests that the observed distributions are due to an intensification of the convection of the ITCZ over the reliefs and to more local circulations, notably slope wind, sea breeze, and monsoonal circulation generating low and middle clouds of convective and stratiform types. Incidentally the ratio of convective to stratiform components of clouds and precipitation is found to be higher for the Fouta Djallon

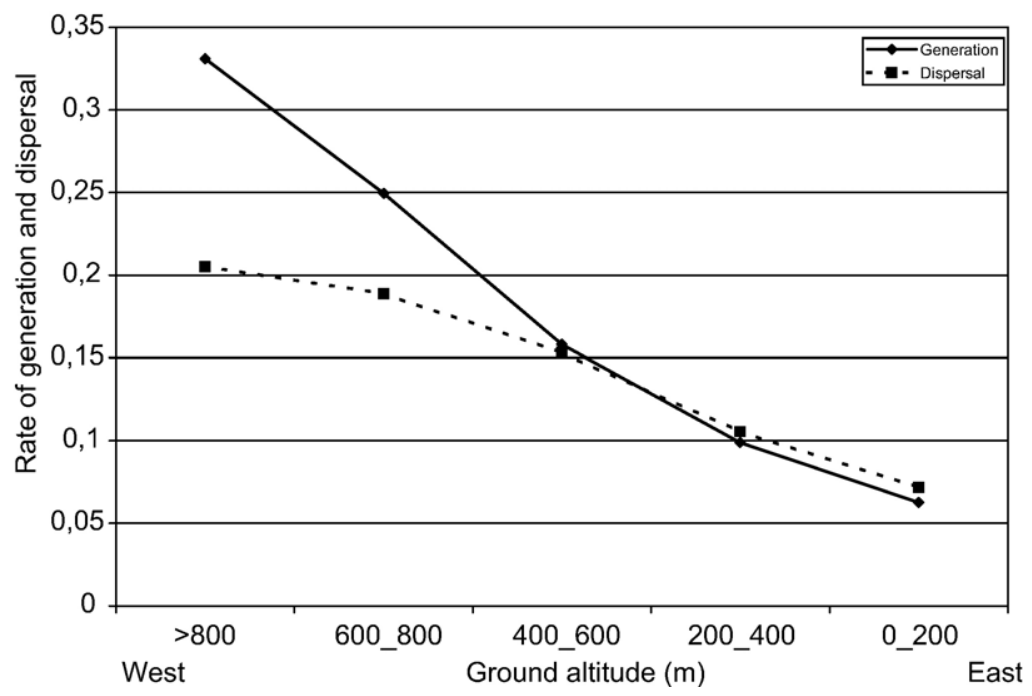

Fig. 11. Generation and dispersal rate of cloud systems for increasing surface altitude, from east to west, up to the top of the Fouta Djallon averaged from 1989 up to 1998, from data of the Meteosat satellite (from Sall and Gaye, 2003). 

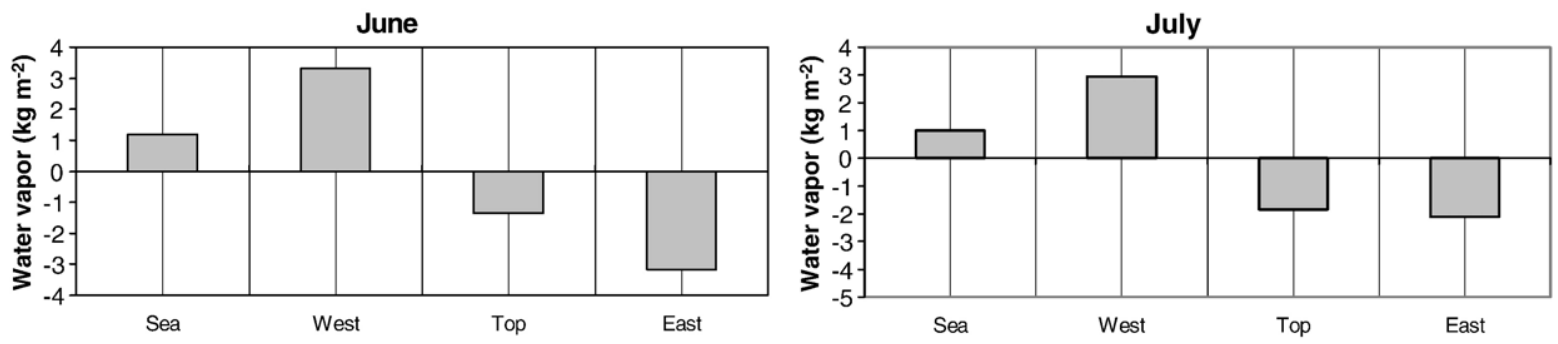

August
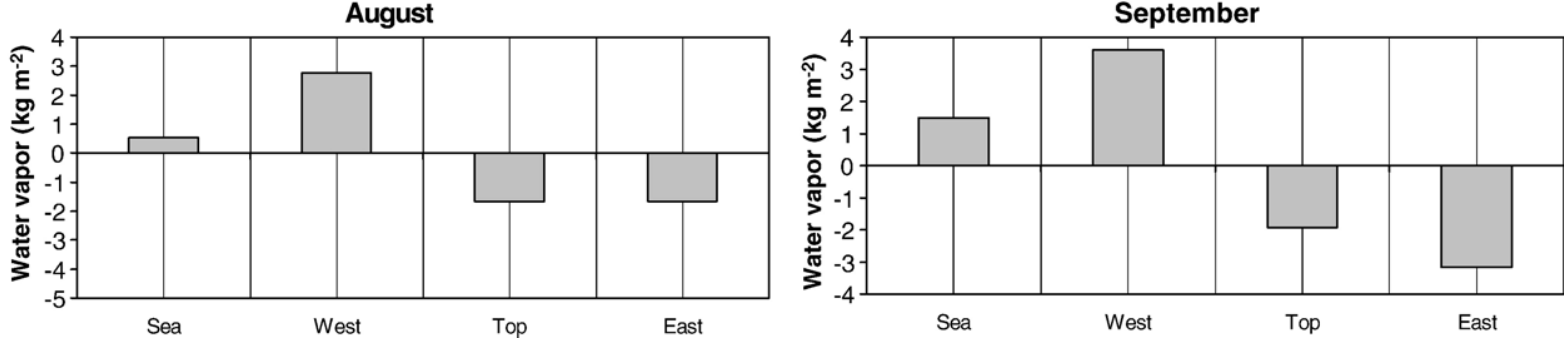

Fig. 12. Differences between the monthly average of vertically integrated water vapor content in the zone $\left(5^{\circ} \mathrm{N}-15^{\circ} \mathrm{N}\right),\left(2.5^{\circ} \mathrm{W}-20^{\circ} \mathrm{W}\right)$ averaged from 1989 to 1998 and monthly average over the same period observed in the four areas of Fig. 1 for the months of the rainy season (from reanalyses of ERA 40).

area than for the Mount Cameroun-Adamaoua one (for reasons whose analysis is out of the scope of the present paper).

\subsection{Mesoscale analysis for the Fouta Djallon area}

The curves of Fig. 11 show the rate of generation and dispersal of cloud systems for increasing altitudes, from East to West, up to the top of the Fouta Djallon relief.
This rate is defined as the ratio of the number of cloud system generations or dispersals to the number of pixels having a given altitude in a grid mesh of $\left(0.01^{\circ}\right)^{2}$. Fig. 11 shows that generation and dispersal of cloud systems increase from East to West, from low levels up to the top of reliefs. In Africa, the main mountainous areas are generally found to correspond to maxima of cloud cover (Sall et al., 1999; Mathon and Laurent, 2001). From $600 \mathrm{~m}$, the curve of dispersal is below that
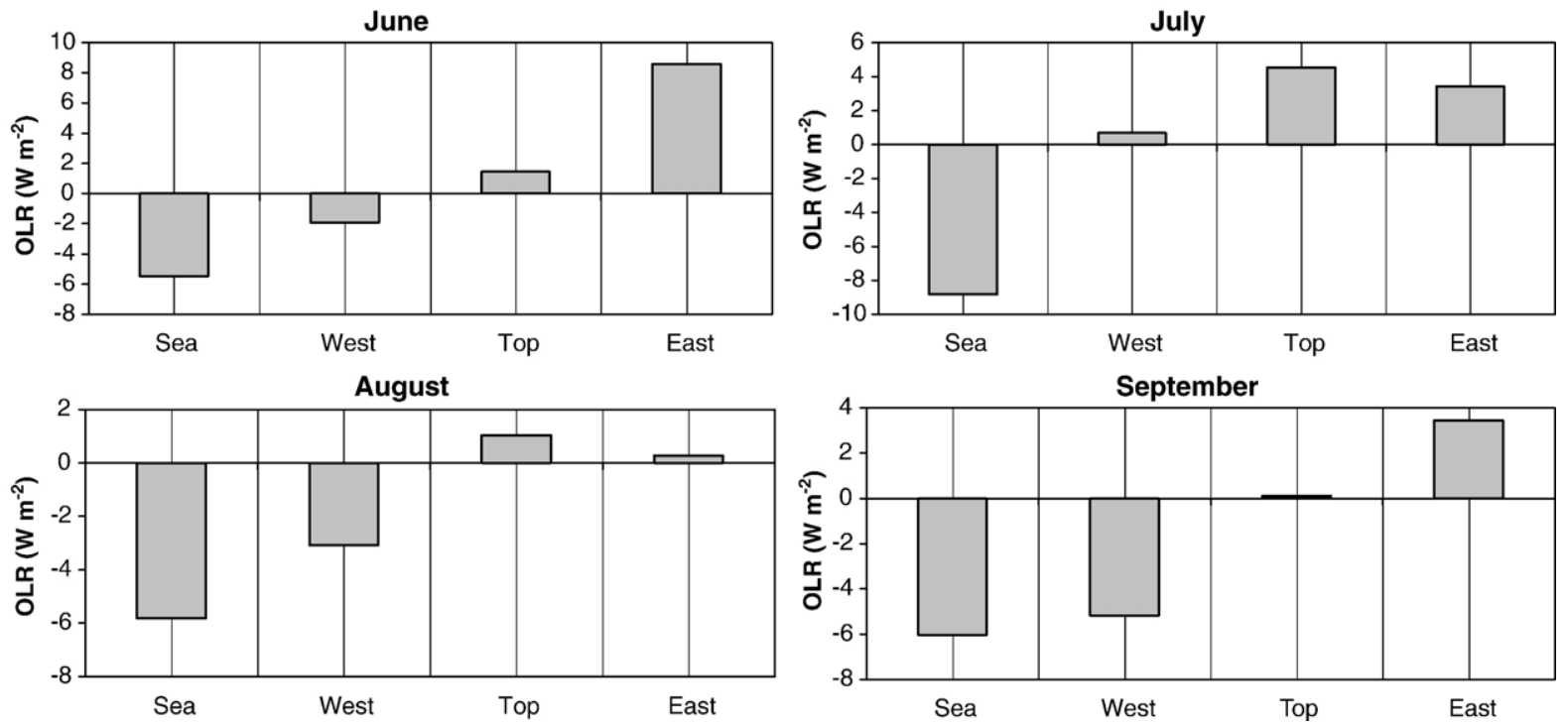

Fig. 13. Same as Fig. 11 for OLR. 


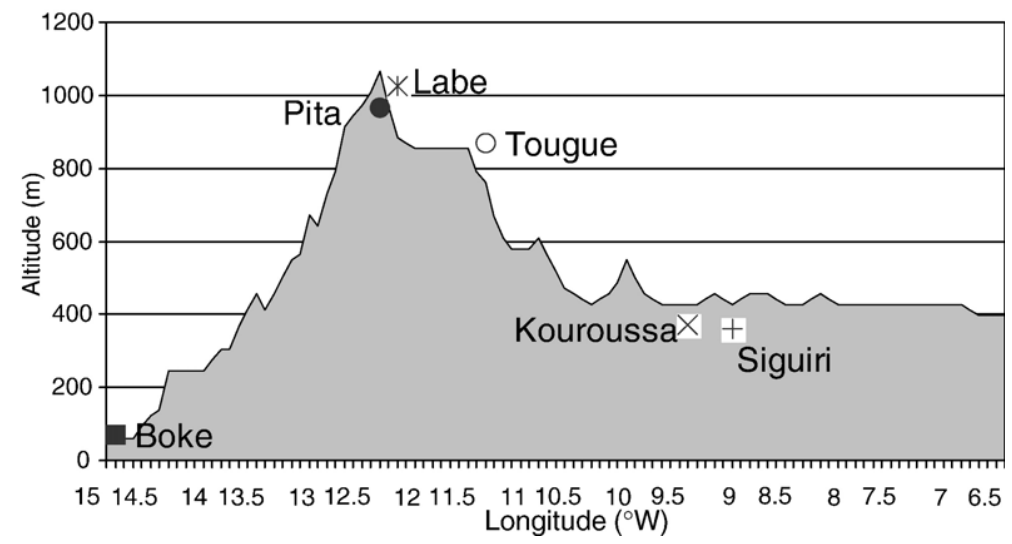

Fig. 14. Maximum altitude of relief between $10.5^{\circ} \mathrm{N}$ and $11.5^{\circ} \mathrm{N}$ as a function of longitude, and location of six hydrologic ground stations.
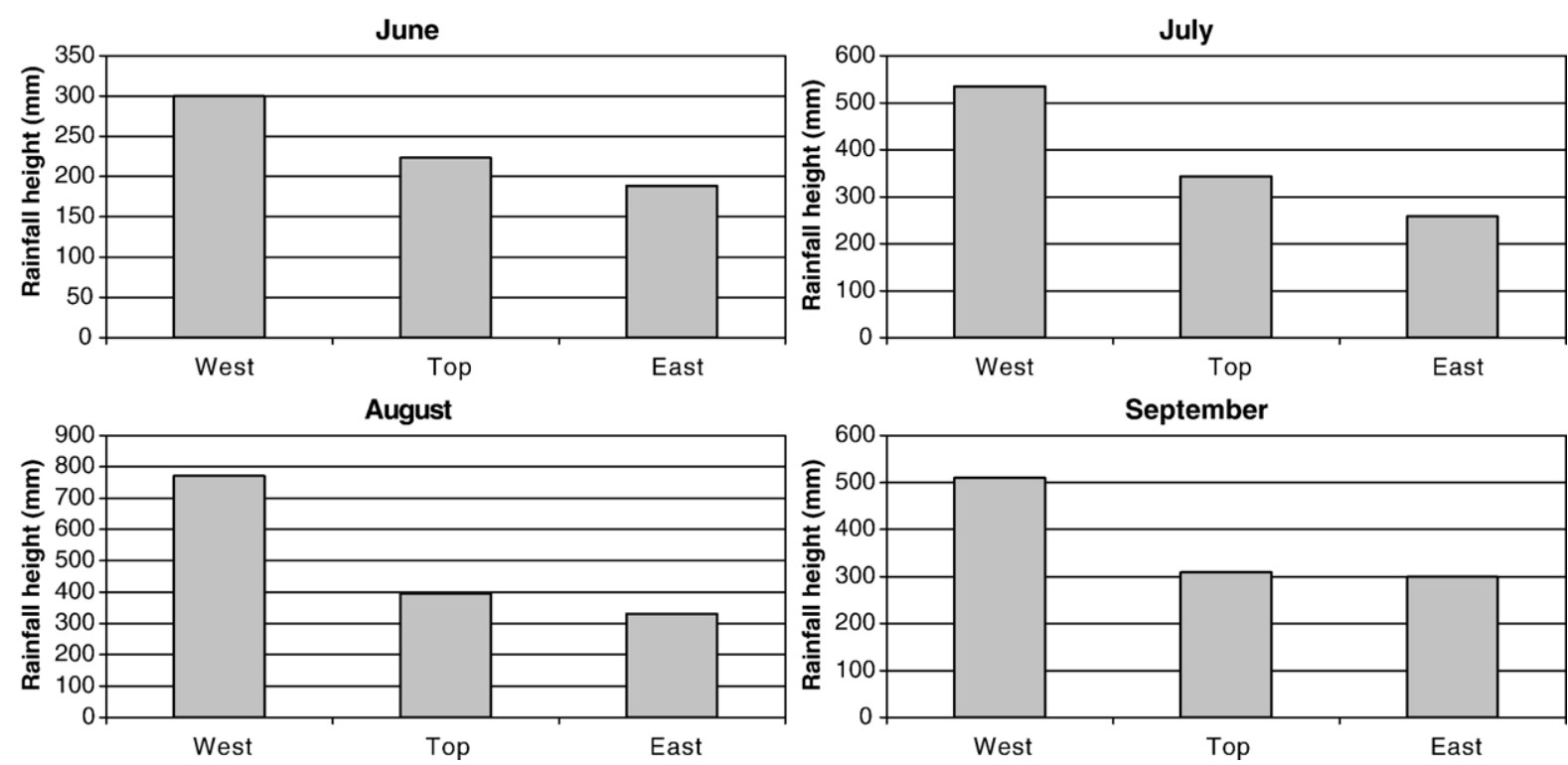

Fig. 15. Distribution of monthly rainfall height averaged from 1925 to 1975 for JJAS (from data of Nicholson et al. 1988).

of generation, showing that the upper part of the Fouta Djallon mountains is more favourable to generation than to dispersal.

Fig. 12 presents the difference between the monthly average of water vapor contents (vertically integrated) in the zone $\left(5^{\circ} \mathrm{N}-15^{\circ} \mathrm{N}\right),\left(2.5^{\circ} \mathrm{W}-20^{\circ} \mathrm{W}\right)$ and the monthly average of water vapor in the four areas of Fig. 1 for the rainy season (JJAS). It can be observed that, for the whole season, there is more water vapor available in the atmosphere west of the reliefs than in the observed areas. This spreading is coherent with the precipitation maxima observed over this area (Fig. 2). The differences of OLR (Fig. 13) show that cloudiness is larger west of the Fouta Djallon than anywhere else (the negative differences in OLR correspond to positive differences in cloudiness and reflect the depth of the convective clouds). We suggest that the numerous cloud systems generated east of and over the mountains develop and stretch westward, adding to the almost permanent convection associated with the land-sea contrast in this zone.

Table 1

Characteristics of convective clouds observed over the region of altitude higher than $600 \mathrm{~m}$ during the summer from 1989 to 1998

\begin{tabular}{llll}
\hline Life duration $T(\mathrm{~h})$ & $T \leq 3$ & $3<T<10$ & $T \geq 10$ \\
Average velocity $\left(\mathrm{m} \mathrm{s}^{-1}\right)$ & 10.4 & 11.5 & 15.6 \\
$\begin{array}{l}\text { Distance travelled } \\
\quad\left({ }^{\circ} \text { of longitude) }\right.\end{array}$ & $D \leq 1.10$ & $1.11<D<3.72$ & $D \geq 5.05$ \\
$\begin{array}{l}\text { System number } \\
\quad(\text { annual average) }\end{array}$ & 203 & 115 & 33 \\
\hline
\end{tabular}


Tropopause
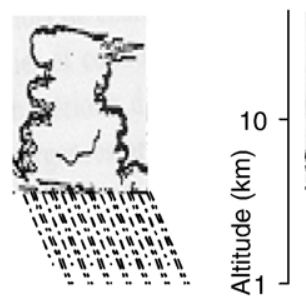

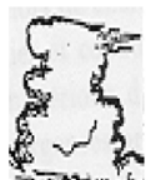

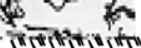

iniminivinitin

कर

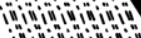

ח?

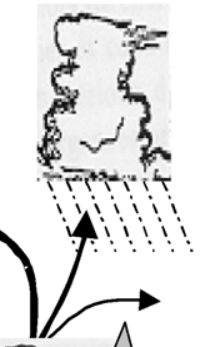

a)

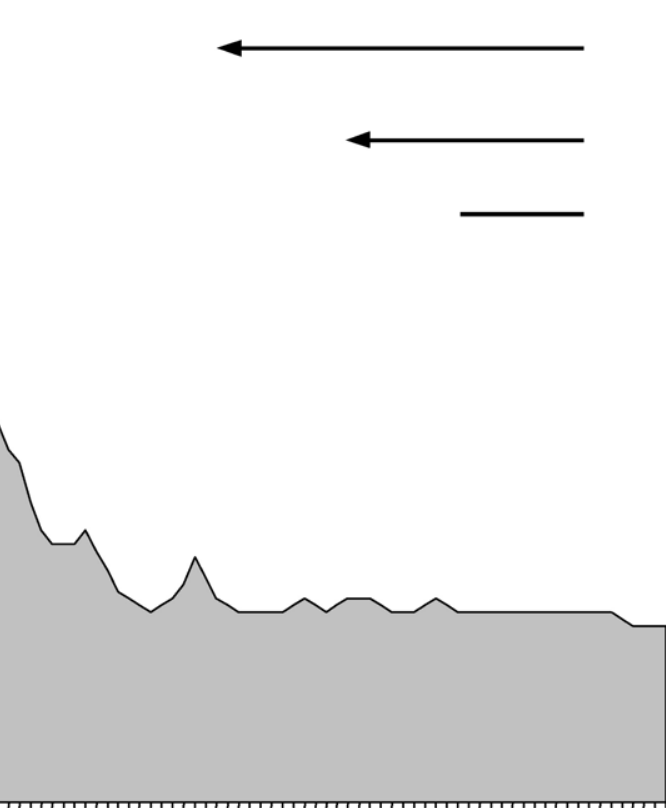

Atlantic Ocean

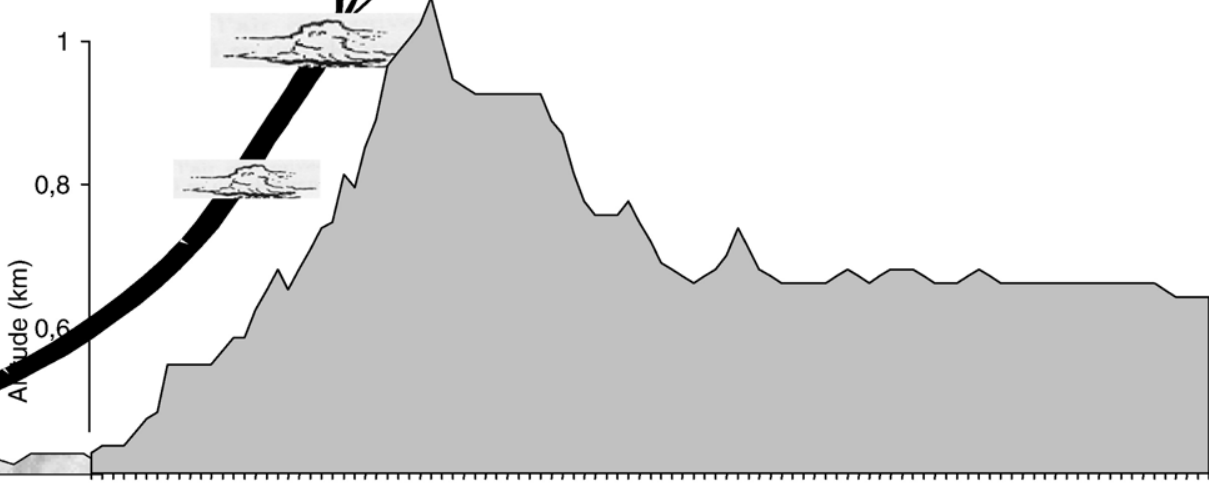

$\begin{array}{lllllllllllllllllllll}15 & 14.6 & 14.2 & 13.8 & 13.3 & 12.9 & 12.5 & 12.1 & 11.7 & 11.2 & 10.8 & 10.4 & 10 & 9.6 & 9.2 & 8.8 & 8.3 & 7.9 & 7.5 & 7.1 & 6.7\end{array}$

Longitude $\left({ }^{\circ} \mathrm{W}\right)$

Tropopause

b)
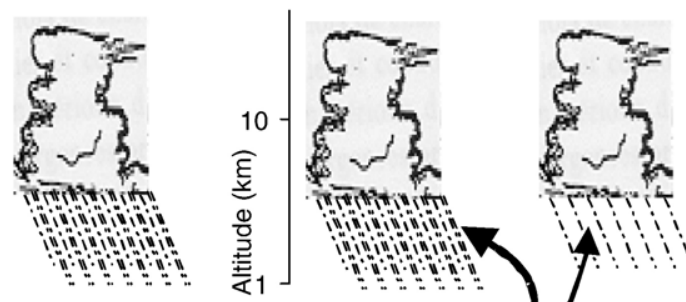

ivivivivivivi

+ha

3

Tat
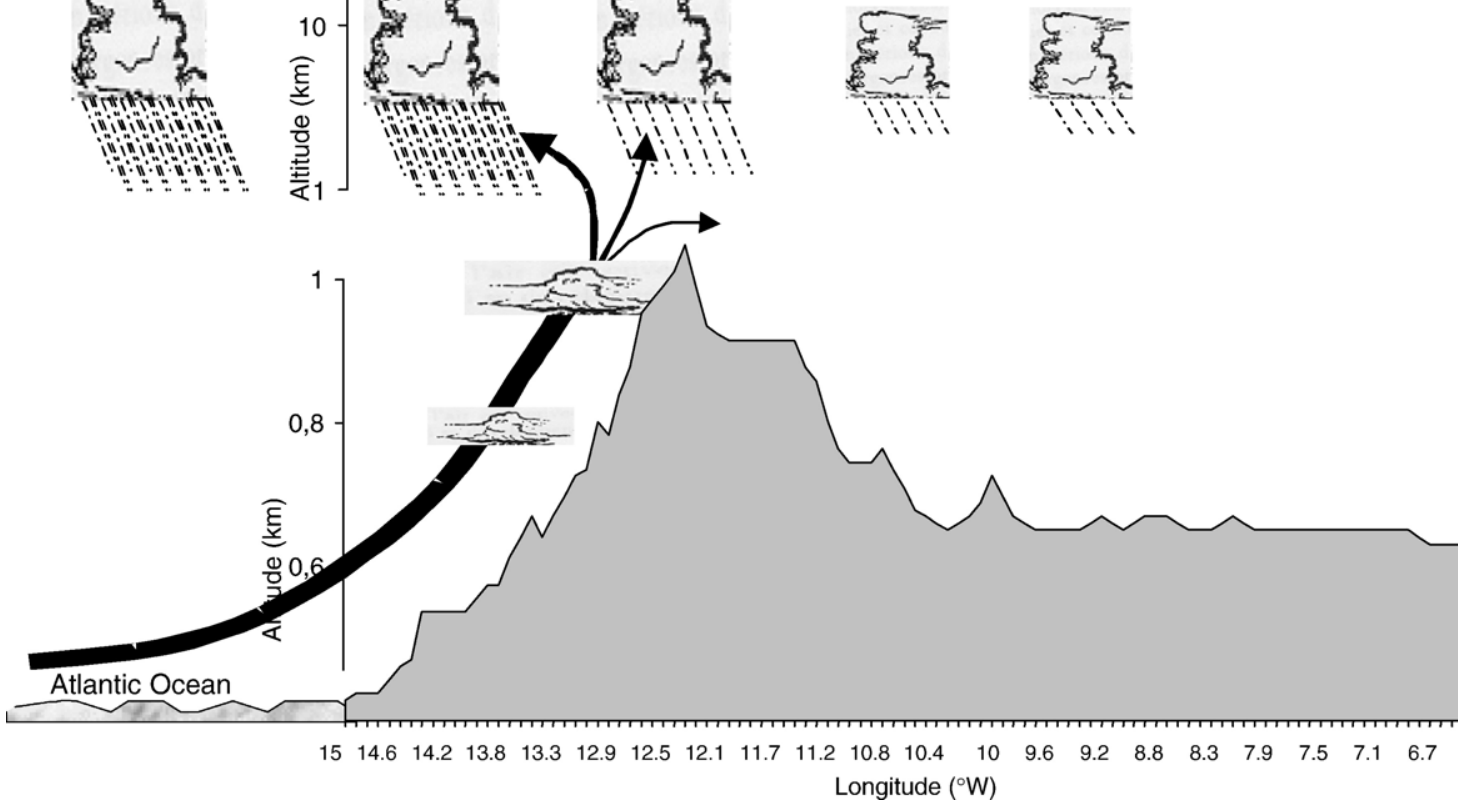

Fig. 16. Conceptual scheme of convection development over the relief of the Fouta Djallon (see text). a) Case of local convection; b) Case of drifting MCSs. 
The maximum altitude of the ground between $10.5^{\circ} \mathrm{N}$ and $11.5^{\circ} \mathrm{N}$ as a function of longitude is presented in Fig. 14. The top of the massif is around $12^{\circ} \mathrm{W}$. The slope of the western side is steeper than that of the east side; over a distance of less than $3^{\circ}$ of longitude, altitude decreases from top (about $1100 \mathrm{~m}$ ) to sea level. In Fig. 14, the locations of five hydrological stations are represented. Rainfall observations (compiled by Nicholson et al. 1988) at these stations are used in Fig. 15 to compare the monthly rainfall height averaged over 57 years (1925 to 1975 for JJAS). Three areas are considered: "east" gathers the stations of Kouroussa and Siguiri, "top" gathers Tougue, Labe, and Pita, and "west" uses the data of Boke. Fig. 15 shows that rainfall observed on the "west" side is higher than that observed at the top and on the "east" side of the massif.

Table 1 concerns the relation between the travelled distance, velocity, and number of cloud systems over the Fouta Djallon. Only systems located over ground of altitude higher than $600 \mathrm{~m}$ (Fig. 3) satisfying the abovementioned criterion for the generation are considered. Table 1 shows that many systems observed around the Fouta Djallon are local systems; $58 \%$ have a life duration lower than $3 \mathrm{~h}$, and a travelled distance smaller than $1.1^{\circ}$ of longitude, that is $110 \mathrm{~km}$. All that they suggests are linked to orographically induced convection developing from the abundant water vapor available over the Fouta Djallon, then carried westward, that is over sea, by general upper air circulation.

Fig. 16 presents a conceptual model of the role of the Fouta Djallon massif on the development of precipitation. Part (a) concerns local convection. Monsoon flux and coastal thermal circulation force a flux of wet air to rise along the western side of the almost perpendicular mountainous barrier. Stratiform clouds are formed at low level along the slope and convection develops higher, over the highest region. These convective clouds are carried westward by the general circulation at upper levels. Since the horizontal velocity of general circulation increases (not continuously) with altitude, the higher the convective clouds, the stronger their velocity westward. The deepest clouds associated with the largest systems have the longest life duration and longest travelled distance. Part (b) concerns the strengthening of MCSs (Mesoscale Convective System) travelling westward over the Fouta Djallon. When passing the crest of the range, the supply of MCSs is suddenly reinforced by the low level wet flux forced upward and eastward along the mountain slope. Intensity of precipitation falling through the low level stratiform clouds is increased by a seeder-feeder process. MCSs thus strengthened have a life duration increased and go farther in their translation westward.

\section{Conclusion}

Using Meteosat satellite images, reanalyses of NCEP/ NCAR and ECMWF, as well as ground raingauge network data, the influence of the Fouta Djallon Massif on the rainfall distribution is analysed. Observations show that the Fouta Djallon area is a region of higher convective activity and cloud generation than lower and flatter environmental regions. The rate of cloud generation is found increasing with the height of the relief.

A conceptual model explaining the maximum of the rainfall height distribution over the sea, west of the Fouta Djallon, is proposed. Monsoonal and thermal low level coastal circulation supplies in humidity the onshore, eastward-directed air circulation forced along the slope of the west side of the Fouta Djallon. Stratiform clouds develop at low level but as one goes along the slope, toward higher level, convective clouds start and deepen. Above the reliefs, convective clouds are carried offshore by the general westward circulation whose velocity increases with altitude. The deeper the clouds and the higher their summit, the larger their horizontal velocity and travelled distance. A similar mechanism works on the MCS originating east of the mountains and advected westward over the massif. When crossing the crest of the range, supply in humidity of cloud updrafts is boosted by the uprising wet air current forced upward by the low level circulation. When falling through the low level stratiform clouds, precipitation amplifies by a seeder-feeder process. Of course other processes can possibly contribute to the Fouta Djallon rainfall distribution. For example, an increase in sea surface evaporation rate due to decrease of upper water layer salinity by rainfall, not discussed in the present paper because the required data are not available, is of particular interest. However orographic effects are the main cause of the observed distribution.

\section{Acknowledgments}

The authors are very grateful to the National Centers for Environmental Predictions/National Center for Atmospheric Research and to the European Centre for Medium-Range Weather Forecasts for providing freely the data used in this paper. Many thanks to an anonymous reviewer for valuable comments and suggestions.

\section{References}

Arkin, P.A., 1979. The relationship between fractional coverage of high cloud and rainfall accumulations during GATE over the B-scale array. Mon. Weather Rev. 107, 1382-1387. 
Arkin, P.A., Meisner, B., 1987. The relationship between large-scale convective rainfall and cold cloud over the Western hemisphere during 1982-1984. Mon. Weather Rev. 115, 51-74.

Arlene, G., Laing, A.G., Fritsch, J.M., 1993. Mesoscale convective complexes in Africa. Mon. Weather Rev. 121, 2254-2263.

Arnaud, Y., Desbois, M., Maizi, J., 1992. Automatic tracking and characterization of African convective systems on Meteosat pictures. J. Appl. Meteorol. 31, 443-453.

Desbois, M., Kayiranga, T., Gnamien, B., 1989. Diurnal cycle of cloudiness over tropical Africa observed from Meteosat: geographic characterization and interannual variations. Ann. Geophys. 7, 395-404.

Diedhiou, A., Janicot, S., Viltard, A., de Félice, P., Laurent, H., 1999. Easterly wave regimes and associated convection over West Africa and Tropical Atlantic: results from the NCEP/NCAR and ECMWF reanalyses. Clim. Dyn. 15, 795-822.

Eltahir, E.A.B., Gong, C., 1996. Dynamics of wet and dry years in West Africa. J. Climate 9, 1030-1042.

Gaye, A., Viltard, A., de Félice, P., 2005. Squall lines and rainfall over Western Africa during summer 1986 and 87. Meteorol. Atmos. Phys. 90, 215-224.

Grist, S.A., Nicholson, 2001. A study of the dynamic factors influencing the variability of rainfall in the West African Sahel. J. Climate 14, 1337-1359.

Hastenrath, S., 1995. Climate Dynamics of the Tropics. Kluwer, Dordrecht. $488 \mathrm{pp}$.

Houze, R.A., 1977. Structure and dynamics of a tropical squall-line system. Mon. Weather Rev. 105, 1540-1567.

Kalnay, E., Kanamitsu, M., Kistler, R., Collins, W., et al., 1996. The NCEP/NCAR 40-year reanalysis project. Bull. Am. Meteorol. Soc. 77, 437-471.

Kebe, C.M.F., Sauvageot, H., Nzeukou, A., 2005. The relation between rainfall and area-time integrals at the transition from an arid to an equatorial climate. J. Climate 18, 3806-3819.
Laurent, H., 1996. Life distribution of mesoscale convective clouds over Africa. Preprints 7th Conf. on Mesoscale Processes (AMS, RMS), 9-13 September 1996, Reading UK.

Martin, D.W., Schreiner, A.J., 1981. Characteristics of West African and East Atlantic cloud clusters: a survey from GATE. Mon. Weather Rev. 109, 1671-1688.

Mathon, V., Laurent, H., 2001. Life cycle of the Sahelian mesoscale convective cloud systems. Q. J. R. Meteorol. Soc. 127, 377-406.

Nicholson, S.E., Kim, J.Y., Hoopingarner, J., 1988. Atlas of African Rainfall and its Interannual Variability. Fla. State Univ., Tallahassee. 237 pp.

Nicholson, S.E., Grist, J.P., 2003. The seasonal evolution of the atmospheric circulation over West Africa and Equatorial Africa. J. Climate 7, 1013-1030.

Plumb, R.A., Hou, A.Y., 1992. The response of a zonally symmetric atmosphere to subtropical thermal forcing. J. Atmos. Sci. 49, $1790-1799$

Rowell, D.P., Milford, J.R., 1993. On the generation of African squall lines. J. Climate 6, 1181-1193.

Sall, S.M., Gaye, A.T., 2003. Relations entre relief, systèmes convectifs et precipitation dans le Fouta Djallon en Guinée. Ass. Int. Clim. 15, 341-348.

Sall, S.M., Sauvageot, H., 2005. Cyclogenesis off the African Coast: the case of Cindy in August 1999. Mon. Wea. Rev. 133, 2803-2813.

Sall, S.M., Gaye, A.T., Fongang, S., Viltard, A., 1999. Génération et dissipation des systèmes convectifs sur l'Afrique de l'Ouest durant l'été 1993. Ass. Int. Clim. 12, 422-429.

Sall, S.M., Sauvageot, H., Gaye, A., Viltard, A., de Felice, P., 2006. A cyclogenesis index for tropical Atlantic off the African coasts. Atmos. Res. 79, 123-147.

Thorncroft, C.D., Blackburn, M., 1999. Maintenance of the African Easterly Jet. Q. J. R. Meteorol. Soc. 555, 763-786. 